\title{
City futures in transformation: Emerging issues and case studies
}

\author{
Sohail Inayatullah \\ 29 Meta Street, Mooloolaba, Queensland 4557, Australia
}

A R T I C L E I N F O

Article history:

Available online 24 May 2011

\section{Cities as agents of global change}

In recent years, cities seem to have been taking greater initiative in global policy making. For example, in May 2005, the Mayor of Seattle, Greg Nickels, led a consortium of the mayors of 131 United States cities to fight global warming by reducing greenhouse emissions, in spite of the fact that the federal government had not signed the Kyoto Protocol [1]. By November 2009 this consortium had grown to include 900 mayors. Nickels notes that these 900 mayors represent 80 million Americans, and argues that the consortium illustrates the "increasingly prominent role that cities are playing in combating climate change" [2]. Another example comes from Australia, where, with similar initiative, the then Lord Mayor of Brisbane [3], Jim Soorley, at the onset of the Iraq war, raised the UN flag above city hall. Soorley argued that "the flag sends a strong message against a war which does not have UN approval" [3]. "This flag is a symbol of humanitarian concern, and it's a symbol that we will always search for peaceful resolution for conflict,"he said [3]. For the purposes of this article, these two events should not be seen as challenging federal sovereignty per se, but more as evocative of the agency of the city. Both are examples of cities acting on their own initiative (and in accordance with the wishes of their citizens), against the position of their federal governments.

As well as showing independence from the federal government, like Seattle and Brisbane, many cities (and local governments) are beginning to imagine alternative futures for themselves that go beyond the tradition of only providing for roads, rates and rubbish (and safety). In this vein, cities now have the ability to influence climate change in particular and the future in general; this may be directly through changes to building codes (creating energy efficiency), and infrastructure planning (moving to light rail, improving bicycle infrastructure, changing energy inputs for buses and cars the city uses) and less directly through, for example, education campaigns.

But this effort has not been without resistance. For example, Steve Nicholas, the former director of Seattle's Office of Sustainability and Environment, recalls that, when Seattle started its global-local effort to combat climate change, a typical comment was: "You're just a city, you have to fill potholes and keep cops on the street" [2]. With many cities bursting with growing populations and with citizens feeling overwhelmed, even exhausted, by the roller coaster of globalization and the associated systemic crises (financial, health), regaining agency has even greater importance.

Because of the challenges of climate change, globalization, and demographic shifts, not to mention safety and security concerns, many cities have begun to place greater planning emphasis on their long term futures. Often this is a shallow adventure of merely purchasing the used futures of other cities. For example, while many American and Australian cities are moving away or have moved away, at least conceptually if not in practice, from the 'big city' Los Angelization model (sprawl,

E-mail address: s.inayatullah@qut.edu.au. 
size and money with associated problems of loss of place and health and increased crime) and toward creating urban villages, many Asian cities remain locked in the bigger is better race/contest/fight for the tallest building [4]. They seem to delude themselves with the view that size and imitation will differentiate in a global economy. For example, recently the former chairman of Petronas, Tengku Razaleigh, has argued that Malaysia's oil economy has been a curse as it has led to maldevelopment. He writes:

the oil that was meant to spur our transition to a more humane, educated society has instead become a narcotic that provides economic quick fixes and hollow symbols such as the Petronas Towers [which was the world's tallest building from 1998 to 2004]... I would rather have good government than grand government buildings filled with a demoralized civil service. [5]

Indeed, research even suggests that there is a correlation between the building of the tallest skyscraper and the onset of an economic downturn; what has been dubbed 'the erection index' [6]. Skyscraper planning and building begins in the initial boom but instead of being spent on quality of life projects, money ends up in the speculation around the 'world's tallest building'. As Mark Thornton writes in his article "Skyscrapers and business cycle" [7], the "reoccurring pattern of entrepreneurial error that takes place in the boom phase is later revealed during the bust phase".

In contrast to these extravagances is the emergence of the healthy cities movement [8], which already accounts for 1200 cities in 30 European nations with the most recent declaration being the Zagreb declaration titled "Health and health equity in local policies" [9].

Healthy city futures are predicated on the physical, social and radically, as I argue, spiritual determinants of health. This means the inclusion of consideration of the quality of water, air, efficient transport systems, of healthy equity, social inclusion, walking areas, community making and partnership/empowerment (i.e. city design that enables individual and group health) and of issues of meaning, and the impacts of meditation and diet on individual and collective health. For example, recently the city of Ghent, in Belgium, as part of their response to climate change, has begun to 'stimulate' citizens to go vegetarian on Thursdays. Councillors have called "for meat-free meals to be served in schools and public buildings, and encouraging vegetarian eateries" [10]. City councillor Balthazar argues that there are "four reasons for eating more vegetarian: it is healthy, it is good for the planet (and climate), it is good for the animals, it is good for people in the south and (most of the times) it is very tasty". The Australian city of Sydney is also, as part of its Green New Year's resolution, suggesting citizens eat one less serve of meat each week, carry their own water bottle (instead of purchasing disposable ones) and put a 'no junk mail' sticker on the letterbox [11].

Initiatives such as these certainly go beyond ensuring that the city is safe, the garbage is picked up and that traffic flows smoothly. New challenges are forcing new policies in the sites of political participation where change can be made-the city. While one can agree or disagree with eating less meat (or issues around water bottles) the point is that city councils are engaging in such policymaking, which extends their role into highly abstract notions of the healthy city. As interesting in terms of differentiating a city and making novel policy is the city of Esperantina which has proclaimed May 9 a holiday called Orgasm Day. Mayor Filipe Santolia said that while the 38,000 people had been unofficially celebrating orgasm day for years, it was now an official municipal holiday [12].

\subsection{Trends and emerging issues}

Change is afoot. The classical definitions of the city (city beautiful, city efficient, city radical) are being challenged by a number of emerging issues. These issues include:

1. Smart growth: especially urban husbandry, vertical farming and the creation of new civic spaces.

2. Transportation planning: rethinking the role of the car in the city (car free cities and dual-mode transportation systems) and rethinking the role of transport (from a Car for All to Mobility for All).

3. Smart city: the wired city, moving to the intelligent city, even imagining the e-topian city. South Korea has nearly completed the beginning stages of the U-city at Songdo, a totally 24/7 digital city where all information-health, production, consumption, schooling-will one day be digitally tracked [13].

4. Green City: moving from recycling to green architecture to deep sustainability, as with Dongtan Eco-city in China [14]. This is informed by the cradle to cradle perspective developed through the work of Ken Yeang and William McDonough [15].

5. Community and the Healthy City: moving from creating community through appropriate design to a community bill of rights to new indicators of economic development that are community matched.

6. Glocal-ization: between the grand super cities (in size, postmodern) and global-local variations with cities trying to be both global and local at the same time, much like the nation-state. It is an issue fraught with tension and diversity.

\section{The weight of history and the structure of the present}

These trends and issues are only a small part of the story; the urbanization of the planet (by 2050, when the vast majority of people will be living in cities), deep inequity, loss of green space, hyper-urbanization (the rise of the mega city) and the car-road worldview continue. Indeed, David Harvey argues that the modern global city provides one with an "aura of 
freedom provided you have the money" [16]; differentiation and choice are only for the few. Throughout the world, shopping malls and artisanal marketplaces proliferate leading to "pacification by cappuccino" [17]. Instead of major structural changes in the world economic system, cities are creating futures without challenging the deep inequities. Thus although individual cities may become healthier, the system as a whole remains demonstrably pathological.

Mike Davis, urban sociologist, argues in his landmark study, "The Planet of Slums", that "of the 500,000 people who migrate to Delhi each year, it is estimated that fully 400,000 end up in slums" [18]. In his review of Davis' work, Harding writes that the "slumization of the world" deserves more global attention, given that by 2020 half the world's urban population will exist in poverty [19]. And if we add the other killer trend of tobacco related illness, which disproportionately affects the poor (WHO estimates that 1 billion will die this century from lung related diseases, most of them poor people [20]), then the future looks horrifying. Small changes such as giving those who live in slums property rights or Yunus's Grameen Bank microcredit schemes will not change the overall structure of the world system.

However, this article moves from the reality of the present to an ecology of possibilities, exploring potential changes that enhance individual agency instead of becoming defeated by the weight of history, the deep structure of inequity.

The issues I focus on in this article are closer to Henri Lefebvre's notion of the right of the city, instead of the city as a site of authoritarian exclusive power, essentially about private property and the rights that conveys. As Lefebvre has argued, the right of the city represents "social relations, resources and creativity that sustain a full and dignified life" [21], "the right to be fully recognized, the right to information, the right of expression, the right to culture, the right to identity in difference and in equality; the right to self management, that is the democratic control of the economy and politics" [22]. Democraticization is the key in this argument. In "The Right to the City", Harvey argues that crucial to counteracting the neoliberal privatization of the city is the democratization of city space. This essay on city futures moves the debate further, arguing for anticipatory democracy, or the democratization of future time, removing it from developers, city councils and urban planners, to citizens. It thus focuses on the potential for agency challenging structure.

\subsection{Emerging issues}

Taking these issues further, we can speculate on some possible emerging issues related to city futures:

1. From the city defined by geography (by a river, for example) to the city defined by temporality. While cities have focused on land use policy (spatiality), the next wave is likely to be temporal policy. Cities are caught in, and part of, multiple temporalities-industrial 9/5 time; cyber 24/7 time; slow time and the slow city movement; and hyper time (the quickening of time). Developing temporal policy will be an important challenge as more evidence appears about the health costs of industrial 9/5 time (deadlines and heart attacks [23]) and postmodern 24/7 time (the frazzled family). (Managing) time may be the more cost effective way to solve traffic problems, instead of via massive infrastructure development.

2. City governance as a primarily vertical space, multiple space (flat and vertical) to a desired space (vertical plus horizontal and spherical as well as other constructions). Imagining and creating desired city futures is becoming a new, and while not core, important activity [24]. Of course, there is resistance, not from citizens but from local councillors. Staying within traditional notions of representative democracy, they question the role of citizens in visioning broader city futures. Is that not the role of the local councillor? More forward looking politicians, however, are likely to see this as a way of enhancing the efficacy of their role and the role of local government, not diminishing it. To do so, the local politician, the councillor, will need to rethink his or her fundamental role from that merely of representing their constituents (which of course includes stakeholders not living in the city) to that of leadership, brokering ideas and mediating disputing visions. Democracy thus is likely to move from representation to e-governance, with many more types of initiative and referenda. Perhaps the cool dimension of today's media contests (the Idol variant) could be used as a template-a preferred future city idol, if you will.

3. From the city as 'neutral' arbiter of interests groups to city as ethical space. With triple bottom line and a long term orientation, cities more and more are challenged to do the right thing, to be central actors in creating and modeling the good society. They are no longer merely facilitating in a neutral manner various interests (developers, community groups), they have their own meta interest [25]. Cities thus are actively engaged in creating futures and privileging various stakeholders over others. While this has been done in feudal and development contexts, it has not been broad based, nor ethical and rational.

4. From the city as a place where public policy occurs to city as public policy. The city, particularly the postmodern city, is now seen as policy, its actions (naming of streets, for example) iconic. Public policy is not a political process but a representational process-essentially this means that the city itself is a global brand, not simply a place where people live. Economic policy is now moving to the notion of a dream economy [26]. At the very least, creative policy is becoming a crucial dimension in being a global economic player.

5. From the city as infrastructure-roads, water, bricks-to the city as living. The city is moving to biological notions of what it is, not merely industrial ones. This may lead to the Gaian city-sensing the needs of inhabitants (technology becoming invisible); that is, a convergence of smart technology with green values. Phillip Daffara has led research here, exploring the Gaian future on the Sunshine Coast in Australia [27]. 
6. From the city as essentially secular to the city as a spiritual node in planetary consciousness. This perhaps is the most challenging emerging issue. The evolving trend is that of city planning focused on sustainability via the triple bottom lineprosperity, environmental sustainability and social justice-with the emerging issue ( 20 years forward) of the quadruple bottom line [28] adding spirituality as the organizing and the depth factor. Spiritually could even become the fourth bottom line; thus understood, it is about designing cities so they produce environments to lead to a sense of awe, of Shanti and Ananda, of deep reflection on our role and purpose in life. Moving further down the line, this is the notion that the city, and the thoughts of its inhabitants, are becoming part of a noetic transformation of our collective consciousness [29].

\section{The 'how' of city futures}

To respond to these and other potential changes, many cities have embarked on 2030 type projects where they map possible and plausible futures and then create their desired future. In doing this, an initial question is: What are the best methods to map and create city futures? In response, first, it is important to ensure that relevant stakeholders are involved. Generally this means citizen groups (through community associations or direct citizen involvement), leaders (a crosssection of community leaders) and research (empirical research to gauge preferences). Having all three groups involved ensures that the city foresight work is empirically rigorous, democratic, and accesses the best and brightest of the community. The city futures project is best led by planning professionals either within the city authority, the university or a foresight association.

When embarking on a city foresight process, Steven Ames, a community visioning expert who has conducted city futures projects in Portland, Bend City, and Hillsboro, Oregon, and played a role in the Gold Coast and Maroochy visioning projects in Australia, among other cities, suggests the following beginning questions [30]:

- How have we got here? (community profile)

- Where are we now? (trends analysis)

- Where are we going? (visioning)

- How will we get there? (action planning)

Are we getting there? (monitoring)

My own methodology is based on the six pillars of futures studies [31]. These are: mapping the past, present and plausible futures; anticipating emerging issues that are likely to disrupt this map; timing the future, discerning which trends are linear and which cyclical, for example; deepening the future, factoring in the visions and myths of multiple stakeholders, for example, citizens, leaders (from a variety of areas-government, small business, nongovernmental organizations, community groups, corporations, and the environment herself); creating alternatives through scenario planning, asking what are the different futures for the city; and finally, transforming the future by developing a vision of the future and through backcasting developing the necessary steps to achieve the vision. I have used this type of process in a variety of city contexts. Not all projects use all six pillars; however, those city foresight projects that have depth and are sustaining certainly tend do.

\section{Case studies}

I now present brief case studies of city foresight as themes. The themes are: single issue, multiple issues, differentiation, long term process, success creates success and multiple cities.

\subsection{Single issue: climate change-Victoria Coast Councils}

In a project for the Victoria Coast Councils, a particular concern was prominent: sea level rise caused by global warming leading to negative impacts on the coast. These negative impacts included the loss of tourist industry, enhancing inequity as the most vulnerable are likely to face the impacts more directly than others (who can move, for example), and impacts on nature herself. The project consisted of introducing foresight concepts to directors, CEOs, and social and environmental planners and then moving toward a shared vision. Through new methods and tools, it was hoped that the capacity to map and influence the future would increase. Unique also in this project was a 40 -year time frame. The participants wanted to begin the process of thinking about 2046 since they understood that climate change was a long term issue. The first phase was getting agreement on the nature of the problem and learning foresight concepts and methods to engage with the long term future.

4.2. Multiple issues: climate change, searching for differentiation in a world economy and protecting against tourism downturnsGold Coast City Council

Another group that has taken a longer term approach is the Gold Coast City Council (focused on 2038). The first phase of this project has been visioning workshops with boards that advise the political arm of the council. The visions that they produced were suggestive, not in any way representative. Part two of this process has been a series of training sessions for 
managers on foresight tools. Not only have tools been covered, but initial visions for the Gold Coast itself have also been developed. Part three is the Bold Futures process-a deeper foresight process with citizen input being central. This broader process takes a thirty-year time horizon. This approach has been step by step, within the action learning framework. Building stakeholder interest and agreement has been crucial. Simultaneous with this has been a process with city councillors. They too have gone through visioning, scenario development, backcasting and strategy development.

The scenarios included the Big Meltdown (climate change, terrorism and financial crisis as potential drivers), the ICT city (investment in new technologies leading to less dependence on tourism), the Self Sustainable City (investment in green technologies, reclaiming of farmland, urban farming, green building), and the Super City (joining up with Brisbane and the Sunshine Coast to create a mega city).

After opening up to the breadth of alternative futures, the participants narrowed the focus to their desired future. The vision had six main themes: a city leading by example (governance); a city loved for its green, gold and blue (environmental sustainability); a city connecting people and places (community making through ICTs and smart design); a city with a thriving economy (diversification and innovation); a safe city where everyone belongs (inclusion); and a city shaped by clever design (city design).

The challenge has been to link the long term with the shorter term electoral cycle. Councillors, even those focused on the big picture and future generations, need to ensure that there will be financial support beyond their own tenure. And they need to provide evidence to citizens that thinking and working on a thirty-year vision is as important as their immediate needs (funding for parks, for example). Councillors now hope to use the emerging vision as a checklist (along with other criteria) for use in deciding on funding of infrastructure and other projects (what type of buildings, what type of transport and finally desired levels of virtuality).

The Bold Future project has been remarkable because of the involvement and inclusion of councillors, administrative staff, urban planners, futurists and citizens. The stakeholder inclusion policy has led to a series of national awards, including in Innovation, Community Contribution and Public Service. The Bold future project has also won an award from the International Association of Public Participation in its core value awards program under the category of "award for decisionmakers" [32]. This award goes to organizations which can demonstrate that people are at the heart of decisionmaking; that is, deep democracy.

\subsection{Ensuring survival by differentiating between larger nearby cities-Logan City Council}

City Directions, a project for Logan City Council, was developed in response to likely changes in the size and borders of cities brought on federal legislation. This project was led by the bureaucracy. While many cities first develop the vision via citizens, Logan decided to first focus on city council professionals. Through a series of foresight workshops, the city council developed: (1) scenarios for the futures of Logan; (2) a vision for the future; and (3) steps necessary to realize the vision.

Four scenarios were developed. The first was an active and healthy scenario of deep participation, moving citizens away from junk food and a sedentary lifestyle to concern with their quality of life and taking steps to improve it.

The second scenario was a green and sustainable future. In this future, Logan would become one of the greenest cities in Australia.

In the third scenario, Logan would become a creative and innovative city-working smarter, using new technologies and investment in the arts were the core characteristics of this future.

The last scenario was Groundhog Day. A future in which no real change occurs-endless public meetings, while the city becomes fatter and less desirable to live in.

The particular output was a city directions policy paper. This policy paper is now undergoing a rigorous consultation process via community workshops. Logan City Council has also included paintings and other creative art forms from young people as part of its visioning process [33]. Along with developing directions, the City administration saw Logan 2026 as a way to develop the city council into a learning organization; that is, to reflect on itself and where it is going. This has been partially successful with City directions being the guiding document as the city goes through the politics of amalgamation.

\subsection{The long term process: success, failure and emerging success. Futures at Maroochy Shire Council}

This project has gone through three phases: (1) hope and excitement about futures thinking, anticipatory democracy, and creating a unique vision; (2) despair around local politics, real politic and a delinking of the vision with budgets and urban planning; and (3) a new city council that has renewed community and city visioning and begun to implement parts of the earlier vision. This process has taken place over three political administrations over a decade.

This project began with a series of breakfast lectures on futures in general and futures of the Sunshine Coast region (the larger region) in particular. These breakfast meetings were attended by hundreds of citizens, including the press, and began the process of community consultation. The second phase was a series of foresight workshops for senior managers. The purpose of these was to introduce foresight methods and tools (scenarios, the futures triangle, causal layered analysis, visioning, and backcasting, for example) and to develop professional capacity to think intelligently and wisely about the future. The third phase was a broader citizen visioning process. This was run by Stephen Ames with local futurists such as Phillip Daffara and Steven Gould providing support [34]. A citizen leaders group championed this process. The fourth phase was empirical research. Data was collected on issues that citizens believed were most important (environment, 
infrastructure) and from these concerns and uncertainties scenarios developed. The fifth phase was a voting day where 400 citizens voted on their preferred future. The voting had some teeth, in that the newly elected Mayor promised that their concerns would be reflected in the corporate plan.

Since then, however, the process has been derailed, not because of lack of citizen engagement but because of local politics. Local councillors opposed to the Mayor have used the foresight process as part of their local political stand-off. This led to the CEO of the Shire moving on to different opportunities. More recently, different shires of the Sunshine Coast region have been amalgamated, a new Mayor and council elected, and the community visioning process has started again; such is the cyclical nature of foresight projects. Noteworthy in assessing the politics of city futures is an MA study by Steve Gould on the Maroochy Shire visioning process. His concluding paragraph links visioning with implementation, finding that the need to keep the trust of the public is a crucial factor in success:

The Maroochy 2025 Community Visioning project was a worthwhile undertaking as it achieved a significant level of community buy-in with to the creation of a sustainable future in partnership with the local government. However, the ongoing value of this opportunity was sadly lost through lack of implementation. Representative democracy and the weight of the past assumption by the community and some local councillors that it is the government's responsibility to plan the future and make it happen, meant a vital opportunity for the community to become empowered and create alternative futures was missed. The newly formed Sunshine Coast Regional Council will find it hard to recover lost levels of trust, perceptions of integrity and respect by the community. However, memories can be short, and in the long term the insights and perspectives gained by undertaking community visioning actions, the significance of this research and lessons learnt-especially through applied futures studies and anticipatory action learning methods-are expected to provide local governments with a framework for transformational change. This could be invaluable in an era in which the creation of sustainable community futures is imperative. [35]

\subsection{Success creates success-visioning and revisioning: Brisbane City Council}

Perhaps the most comprehensive and on-going city foresight process has been undertaken by Brisbane City Council (BCC) [36]. In the early 1990s, BCC began a Brisbane 2010 project. This included visioning for councillors, the professional bureaucracy and citizens. The vision had real teeth in that for projects to be funded they had fit into the directions of the vision. But more than just working to a fixed vision, Brisbane City Council also began a scenario process with policy papers on new issues (the creative city, the inclusive city, e-governance, for example). Along with this has been the Brisbane Ideas festival, which has featured robust debates on the futures of the city, the state and the world itself.

My part was conducting a series of training workshops over a period of three years for more than 150 managers within BCC. These were tools and methods based, focused on rethinking the nature of the organization. As well, particular policy issues were investigated (the futures of aging, the futures of organizations, the futures of values, and contradiction between emerging city futures and the present, for example). The various divisions within the city council have also sponsored numerous one-day workshops on a range of subjects (transport, water, community development, the library, for example).

In 2006, the Vision was refreshed with the Brisbane 2026 project. The success of this process is indicated by the fact that it has continued through the tenures of three different mayors. Indeed, it has been exported throughout Australia and the world. Brisbane's foresight experience was central to the futures focus of the Asia-Pacific Cities Summits in 2003 and 2007. As well, Brisbane has led the way in cities looking a hundred years ahead-particularly around issues of climate change.

Since the Vision's refreshment in the 2026 project (and this is part of the pendulum swing of local politics), the focus has not been on challenging the current direction of the city but on implementing large scale infrastructure projects, such as building tunnels. The move has been from the soft systems cultural approach of city futures to the hard engineering approach. Futures qua alternatives moved to a particular future. Most likely, once the tunnels are built (and hopefully, there is not a correlation between tunnels-as lying down skyscrapers-and recessions), ${ }^{1}$ the soft systems approach will return.

\subsection{Multiple cities-Asia-Pacific cities summit, 2003 and 2007}

Foresight can also be used to aid groups of cities or city leaders to develop their futures. The 2003 Asia-Pacific Cities Summit was entirely futures focused. The themes of the conference were developed from an environmental scan titled City Futures (available from www.metafuture.org). Five themes were articulated: (1) transforming sprawl; (2) greening cities; (3) creating healthy communities; (4) glo-cal governance; and (5) alternative futures of the city. At the conference, attended by over 500 city leaders, including mayors, CEOs, planners, developers, and environmentalists, the three days were organized around: (1) current and emerging issues facing cities; (2) scenarios; and (3) preferred futures. The immediate issues articulated by mayors included: population drift (rural to city, small to large cities); traffic congestion; growth occurring faster than infrastructure development; lack of partnership between city and business; loss of cultural heritage; long term

\footnotetext{
${ }^{1}$ Steve Gould argues their similarity, i.e. large infrastructure projects that skew the local economy, appearing to solve problems but often lead to unintended consequences that do not truly solve the problem. And while the current recession has spread from the USA, certainly the high debt burden Brisbane is now facing will not ease long term recovery. Personal communication, 14 January 2010.
} 
water supply; lack of skills of the workforce; lack of support of central government to local government; and lack of employment opportunities.

Emerging issues seen by these city leaders included-along with the expected issue of the increased income gap between the haves and have-nots being created by globalization-that the future would make their roles far more complex. They would have to address issues such as the ethics associated with medical and technological advances, e-governance, as well the broader issue of the role of the civic leader in a digitalized e-city. And along with a squeeze from the central governmentin terms of fewer funds but more responsibilities-mayors would be caught in a squeeze from nature, with extensive competition for water and other natural resources. Aging as well would change the nature of the city, leading some cities to be increasingly dysfunctional and others becoming retirement centres. Along with the demographic shift of aging, immigration-especially the new wave of global knowledge workers (and refugees)-would change the face of the city.

The scenarios developed were: (1) high tech anomie where digitalization leads to a loss of community; (2) disaster management, where cities would be the focus of a great deal of environmental, political and health crises because of globalization, terrorism and climate change; and (3) changing expectations, where the role of city governance would change as citizens expected more from their leaders. Democratization, globalization, a highly educated, technology savvy population demanding instant response from cities would lead to a condition of permanent crisis. Leadership would succumb to these pressures and citizens would resort to undemocratic expressions to get their needs met. The fourth scenario was: Creating learning organizations and communities. In this future, cities would become the vehicle by which citizens can take far more responsibility for the future of their city. Part of being a learning community was to embed in the city processes of conflict resolution-mediation and arbitration-so that the rights of individuals and groups and the pressure of social advancement could be negotiated.

Of the preferred futures, two factors stood out. The first centred on the size of the city and the scope of economic development. This was the international city, where economic growth was primary. The second was the rainforest city-in which the triple bottom line of prosperity, social inclusion and sustainability was primary. It was not the size of the city but the quality of life that was foremost. The 2007 Asia-Pacific Cities Summit, again hosted in Brisbane, continued this foresight process but now focused on the visions of youth leaders. The foresight process first examined their preferred future. Second it looked at what is missing in this future, or what is disowned. Finally, these two aspects of the future were integrated. Among the main points of their vision were: triple bottom line cities (prosperity plus social inclusion plus environment sustainability); cities designing space for health conflicts (as opposed to repressing conflict or ignoring it); and cities working toward an Asia-Pacific Union.

More recently at the 2007 Asia-Pacific Cities Summit, foresight moved from helping mayors rethink the future, to working with youth representatives from cities. Foresight theory and methods were used to help them develop their personal and organizational capacity to influence the long term future. Mayors rightfully understood that futures thinking is generational. Creating partnerships among youth representatives (those below 25 working in cities around the Asia-Pacific region) was a crucial step in ensuring that implementation of visions was possible.

\section{Lessons}

These case studies, while all Australian based, do give us the following lessons. City foresight needs to be embedded in solid methods and tools. These methods must move from mapping the future to critically challenging used and disowned futures and then to the desired future. Finally strategies to realize visions must be central to the planning process. Implementation is best done via the action learning model, where learning is cyclical and occurs through doing. As importantly, city foresight needs to be as inclusive as possible. City foresight properly done will not be a hostage to political processes. Councillors needs to be included in this process and shown how the long term vision can be linked to the short term electoral cycle. Furthermore, the outputs of city foresight are not just a vision of the future, but an enhanced capacity of professionals in the bureaucracy and citizens to develop the futures they desire. While these claims cannot at this stage be empirically proven, it is hoped that current research on city futures meanwhile provides evidence that foresight is effective. Finally it is crucial for the practitioner to note that there are political pendulums of the move from left to right, from mayors focused on social issues to mayors focused on engineering and infrastructure issues. Different foresight processes are necessary for different phases in city planning and development.

\section{Conclusion: changing the global political landscape}

Can we then imagine a world future where along with nations, corporations, and nongovernmental organizations, cities will be full players. With over $50 \%$ of the world's population living in cities, it is clear that blindly running toward the future is no longer viable nor is trusting to market forces alone [37]. Are we then entering a spiral turn with the return of the city-state (is Singapore a leading indicator)? It is far from clear if this is the case; certainly as the nation-state loses its relative importance, other actors are moving in. Cities are crucial in this transformation of global space. Can they play a role in creating a more equitable global ecumene, system? That remains uncertain. But with their re-conceptualization of the global, they can play more effectively at the local. The trends and issues articulated in this piece suggest that citizens are far more active. E-democracy, neighbourhood mediation centres, community visioning and even local community consultation are changing local politics. 
From above and below, cities are influencing what is, and what can be. Engaging in the theories and methods of futures studies can help in this practice. Agency can be victorious over structure.

\section{References}

[1] E. Sanders, Seattle leads US Cities in joining Kyoto Protocol, International Herald Tribune, May 16, 2005 http://www.iht.com/articles/2005/05/15/news/ global.php (accessed 8.10.07), Also see http://www.c40cities.org/. C40 is a group of the world's largest cities focused on the challenges of climate change..

[2] L. Winerman, Cities, Towns Work to Combat Climate Change, PBS Newshour (online), March 23, 2009 http://www.pbs.org/newshour/updates/science/ jan-june09/climatecities_03-23.html.

[3] Soorley ruffles feather in UN flag flying, ABC News (online), March 21, 2003 http://www.abc.net.au/news/stories/2003/03/21/813097.htm (accessed 8.10.07).

[4] http://www.apcsummit.org/history/content/?id=175.

[5] http://razaleigh.com/2009/12/12/a-blessing-become-acurse/ (accessed 12.01.10).

[6] The Large Erection Index predicts recession for China, Asia pacific Management News, February 23, 1999http://www.apmforum.com/news/apmn237.htm (accessed 14.01.10).

[7] M. Thornton, Skyscrapers and Business Cycles, Mises Daily (online), August 23, 2008 http://mises.org/story/3038 (accessed 14.01.10).

[8] Healthy cities and Urban Governance, March 12, 2009 http://www.euro.who.int/Healthy-cities (accessed 14.01.10).

[9] Zagreb Declaration for Healthy Cities: Health and health equity in all local policies, World Health Organization, 2009http://www.euro.who.int/Document/ E92343.pdf (accessed 12.01.10).

[10] E. Harrell, Where's the Beef? Ghent Goes Vegetarian, Time.com, May 27, 2009http://www.time.com/time/world/article/0,8599,1900958,00.html (accessed 3.02.10)..

[11] City of Sydney, Live Green (newsletter), 2010 http://www.cityofsydney.nsw.gov.au/Newsletters/livegreen/ (accessed 3.02.10).

[12] http://www.freerepublic.com/focus/f-chat/1399804/posts (accessed 12.01.10).

[13] International herald Tribune: http://www.iht.com/articles/ap/2006/11/23/business/AS_TEC_SKorea_Cyber_City.php (accessed 23.08.08).

[14] Shanghai plans eco-metropolis on its mudflats, originally published in The Observer, January 8, 2006, guardian.co.uk: http://www.guardian.co.uk/china/ story/0,1681385,00.html (accessed 8.10.07).

[15] W. McDonough, M. Braungart, Cradle to Cradle: Remaking the Way We Make Things, North Point Press, 2002http://www.mcdonough.com/. For more on Ken Yeang, go to: http://eng.archinform.net/arch/8619.htm?scrwdt=1280 (accessed 8.10.07).

[16] D. Harvey, Right to the city, New Left Review 53 (September-October) (2008) 31.

[17] D. Harvey, Right to the City, New Left Review 53 (September-October) (2008) 31-32.

[18] M. Davis, Planet of Slums, Verso, London, 2006, quoted in Jeremy Harding, It migrates to them, London Review of Books 29 (5) (2007) 25-27.

[19] J. Harding, It migrates to them, London Review of Books 29 (5) (2007) 25-27, http://www.lrb.co.uk/v29/n05/jeremy-harding/it-migrates-to-them (accessed 14.01.10).

[20] 1 Billion Smokers will Die this Century, Medical News TODAY, 2 June 2003 http://www.medicalnewstoday.com/articles/3693.php (accessed 14.01.10).

[21] Cited in M. Purcell, Recapturing Democracy: Neoliberalization and the struggle for alternative urban futures, Routledge, New York, 2008 , p. 94.

[22] http://forum.unhabitat.org/forum_posts.asp?TID=20076\&title=what-is-the-right-to-the-city (accessed 14.01.10).

[23] http://www.ediets.com/news/article.cfm/cmi_990411 (accessed 8.10.07).

[24] See the work of Steve Ames-www.communityvisioning.com/stevenamesbio/.

[25] See, for example J. Galtung, Cities for People, Cities for Peace, Cities for the Future, 2007 http://www.transcend.org/t_database/articles.php?ida=138 (accessed 8.10.07).

[26] See J. Dator, Y.-S. Keo, Korea as the wave of a future: the emerging dream society of icons and aesthetic experience, Journal of Futures Studies, 9 (1) (2004) 3144, Full article available from: www.jfs.tku.edu.tw.

[27] See Daffara - www.futuresense.com.au.

[28] See www.metafuture.org/Articles/spirituality_bottom_line.htm. Also see S. Inayatullah, Spirituality and the future bottom line? Futures, 27 (6) (2005) 573-579.

[29] See Phillip Daffara, Macrohistory and city futures, Journal of Futures Studies 9(1) (2004), 13-30. The full article is available at: http://www.jfs.tku.edu.tw. Also see with works of Ervin László, particularly his Science and the Akashic Field: An Integral Theory of Everything, Inner Traditions, Rochester, Vermont, 2004, and P.R. Sarkar, particularly his theory of Microvita. P.R. Sarkar, Microvita in a Nutshell. Calcutta, Ananda Marga Publications, 1993.

[30] P. Ding, Envisioning local futures: the evolution of community visioning as a tool for managing change-an interview with consulting planner and futurist Steven Ames, Journal of Futures Studies 9 (4) (2005) 89-100, Full article is available at: www.jfs.tku.edu.tw.

[31] S. Inayatullah, Six Pillars - futures thinking for transforming, Foresight 10 (1) (2008) 4-21.

[32] http://www.iap2.org.au/awards/cid/22/t/awards.

[33] L. McGowen, H. Russo, Finding our way around the city, Journal of Futures Studies 12 (1) (2007) 131-144, Full article available from: www.jfs.tku.edu.tw.

[34] Gould has written an MA thesis on the topic at the University of the Sunshine Coast evaluating the Maroochy 2020 project. Steve Gould, Creating alternative community futures-a community futures tragedy. Submitted June 2008. Also see his article, S. Gould, Maroochy 2020 Visioning and action, Journal of Futures Studies 10(1) (2005) 125-132.

[35] S. Gould, Creating Alternative Community Futures-A Community Futures Tragedy, University of the Sunshine Coast, Sippy Downs (Queensland), 2008222.

[36] See the stunning booklet, Brisbane City Council, Our Shared Vision: Living in Brisbane 2026. Brisbane, 2006. For more information, visit: www.brisbane.qld.gov.au. Jennifer Bartlett has coordinated these activities. Mike McAllum was the consulting futurist- http://www.globalforesight.net/MainMenu.

[37] UNFPA, Unleashing the Potential of Urban Growth: State of World Population, UNFPA, 2007 http://www.unfpa.org/swp/swpmain.htm (accessed 23.08.08). 